\title{
Factors Hampering Innovation Activities - Case Study from the Czech Republic
}

\author{
Josef Krause ${ }^{1^{*}}$
}

\begin{abstract}
The article looks at the importance of innovation in company strategy. It presents paths to a formulating strategy focused on innovation and approaches to value. It also introduces the main barriers to an enterprise's innovative activities and their types. It gives the key results of research undertaken in the Czech Republic by the Czech Statistical Office on the topic of innovation.
\end{abstract}

Keywords: strategy; innovation; blue ocean strategy.

Submitted: June $30^{\text {th }} 2016$ / Approved: November $25^{\text {th }} 2016$

\section{Introduction}

Innovation is significant for the competitiveness of the whole economy (Scholleova and Necadova, 2012; Necadova and Brenova, 2009). Innovation and innovation strategy are considered one of the ways to achieve a successful strategy and build up competitive advantages (Grant, 2013; Johnson et al. 2011, 2012; Drucker 2015; Wit et al. 2014; Christensen, 2015; Jones, 2012). Rasheed (2012) for example writes "Innovate or perish!" There is a whole range of reasons why innovating businesses are successful. Johnson et al. (2011), for example, give the following advantages: Businesses can benefit from the experience curve; compared to followers, they have the profit of greater experience and contact with production; returns to scale as a result of larger production volume. These returns to scale allow them to achieve lower costs than their competitors. Another benefit of being first on the market is the opportunity to secure a supply of rare inputs which will be difficult for other businesses to acquire. Another reason is the innovator's good reputation amongst customers. The aim of this paper is present the main world and Czech authors emphasizing the importance of innovation for business strategy. The another goal of the article is to introduce chosen results of research realized by the Czech Statistical Office in the Czech Republic focused on the innovation activities in the Czech enterprises.

\section{Innovation strategy}

The topic of the presented article corresponds to the relatively new approach to building a successful strategy formulated by authors Kim and Mauborgne (2004, 2005a, 2005b). They have named this concept the 'blue ocean strategy.' The essence of the blue ocean strategy is creating own industry. Your company will not be competing with anyone else within this new industry. The creating own industry contrasts to a 'red ocean strategy' in which a company competes in industries where there already are competitors. Kim and Mauborgne propose several paths to formulating a blue ocean strategy. These ways should increase the customer value.
The authors reject the traditional dilemma between basic generic strategies formulated by M. E. Porter (1998a, 1998b). These generic strategies include the necessity for differentiation or concentration on lower costs or on the niche. Kim and Mauborgne (2005a) create a systemic framework of four actions (active measures) which are meant to help break this decision-making dilemma. This ambit is defined by the words: eliminate, reduce, create and raise. Businesses must identify factors which the industry takes for granted but can be reduced. Businesses must further identify factors which the industry considers standard but which can be reduced to a lower level. In contrast, factors must be identified which must be raised to a higher standard than is common in the industry. The final action businesses must take to find factors which until now have not been offered in the industry, and these must be created. The basis for successfully creating a blue ocean strategy is value innovation.

The differences between a blue and red ocean strategy can be defined as follows. Typical for a red ocean strategy is (Kim and Mauborgne, 2005a):

- Compete within an existing market space.

- Beat your competitors.

- Exploit existing demand.

- Choose between value and cost.

- Align the whole of your company's activities with its strategic choice of differentiation or low cost.

The characteristics of a blue ocean strategy are (Kim and Mauborgne, 2005a):

- Create an uncontested market space.

- Make the competition irrelevant.

- Create new demand and capture it.

- Break the value-cost trade-off.

- Align the whole of your company's activities in pursuit of differentiation and low cost.

Also, other authors emphasize the importance of innovation for the company success. For example Vlček $(2005,2006$, and 2008) has

(1) The University of Economics, Prague, Faculty of Business Administration, Czech Republic

*E-mail: krausej@vse.cz 
looked in detail at innovation strategies and the importance of value innovation. Vlcek (2008) considers the pair stimuli for product and process innovation in the needs of external customers, and the needs of business units as market participants. He sees incentives for process innovation mainly in the requirements of external purchasers, the needs of business units as producing entities and the needs of some other stakeholders.

We can compare this with Drucker's approach (2015), which differentiates the seven most significant sources of innovation. The first four sources come from within a business:

- unexpected events,

- the discrepancy between reality and what had been anticipated,

- innovations which arise from process changes,

- shifts in the industry for which no-one is prepared.

The sources of innovation which come from outside the business are:

- demographic changes,

- changes in opinions and moods,

- new knowledge both scientific and non-scientific.

Drucker (2015) further formulates the successful competitive strategies: "fastest with the moistest," "hit them where they are not," "ecological niches" and "changing values and characteristics."

Also, Bartes (2011, 2010, 2006), who promotes an approach to formulating a business strategy which is not based on direct competition with rivals, for example, is in agreement with the above-detailed approaches which stress the importance of innovation.

\section{Case study - Czech Statistical Office research - innovation activities of enterprises in the Czech Republic}

According to a survey of the Czech statistical office (2014), the most innovating businesses are in the information and communication technology industry (65\%), the manufacturing industry (48\%) and Wholesale (42\%). Those industries with a pair level of innovating activities include architectural and engineering activities, research and development and others (39\%), electricity, gas, heat and air-conditioning production and supply (36\%) and water storage and activities related to sewage, waste, and sanitation (34\%). Those industries with the lowest level of innovation include mining and quarrying (23\%) and transport and storage (19\%).

\section{Factors hampering innovation}

According to Oslo Manual (2005), there are several factors hampering innovation activities. There are five groups of these factors: cost factors, knowledge factors, market factors, institutional factors and other reason for not innovating. Cost factors are for example lack of funds within the enterprise, lack of finance from sources outside the company, excessive perceived risks. Knowledge factors include for example innovation potential insufficient, lack of information on technology, lack of information on markets, difficulty in finding cooperation partner, organizational rigidities within the enterprise. Market factors include uncertain demand for innovative goods or services and a potential market dominated by established firm. Intuitional factors are a lack of infrastructure, weakness of property rights, legislation, regulations and others. Other reasons for not innovating are no need to innovate due to earlier innovations and no need because of lack of demand for novelty.

Factors hampering innovation activities for enterprises in the CR in 2010 - 2012 are (Czech Statistical Office, 2014):

Innovations not required $33 \%$,

Prior innovation means further innovation not necessary $20 \%$

Uncertain demand for new products $43 \%$,

Monopolised market $32 \%$

Problems finding a co-operating partner $18 \%$,

Lack of information on markets $14 \%$,

Lack of information on technology $8 \%$,

Lack of qualified workers $34 \%$,

High innovation costs $52 \%$,

Lack of funding outside the enterprise $24 \%$,

Lack of funding within the enterprise $56 \%$.

The most common factor hampering innovation activities for companies was a lack of financing within the business (approx. $56 \%$ ). This factor also relates to high innovation costs (approx. $52 \%$ ). For $43 \%$ of firms, the hampering factor is uncertain demand for new products, for $34 \%$ a lack of qualified workers, for $33 \%$ the problem is the fact that innovations are not required. For $32 \%$ of innovating enterprises, the hampering factor is the fact that the market is controlled by established companies. A lack of external sources of funding (24\%) and problems finding a suitable partner with whom to innovate (18 $\%)$ can be said to be relatively less important factors for innovation. A lack of information on markets and technology are amongst the least important factors hampering innovation. For about a fifth of enterprises, their prior innovation activities are an obstacle to new development.

Another field of interest of the research was aimed at the most significant factors hampering innovation activities for enterprises in the Czech Republic during period 2010 - 2012 (Czech Statistical Office, 2014). These factors are:

Innovations are not required $12 \%$

Prior innovation means further innovation not necessary $5 \%$

Uncertain demand for new products $11 \%$

Monopolised market $8 \%$

Problems finding a co-operating partner $1 \%$

Lack of information on markets $1 \%$

Lack of information on technology $0 \%$

Lack of qualified workers $10 \%$

High innovation costs $13 \%$

Lack of funding outside the enterprise $4 \%$

Lack of financing within the company $34 \%$. 
For $34 \%$ of innovating firms, the biggest obstacle is a lack of financing within the business. The other factors looked at follow on with a relatively large gap. For 10 to $13 \%$ of companies, the biggest obstacles are high innovation costs, a lack of demand for novelty uncertain demand for new products and a lack of qualified workers. For 4 to 8 $\%$ of businesses, the most significant factor is a monopolized market, prior innovation and a lack of external sources of funding. An almost negligible number of enterprises (approx. $1 \%$ ) said that the most significant factor was a problem finding a partner and a lack of information on markets or technologies.

Table 1 gives information on the differences in barriers to innovation according to enterprise size. A business with $10-49$ employees is considered a small firm. A business with $50-249$ employees is considered a medium firm. A business with 250 or more employees is considered a large firm.

Table 1. Most significant factors hampering innovation activities according to enterprise size

\begin{tabular}{llll}
\hline Enterprise size & Small enterprises & Medium enterprises & Large enterprises \\
\hline Innovations not required & $14 \%$ & $10 \%$ & $10 \%$ \\
Prior innovation means further innovation not & $5 \%$ & $4 \%$ & $4 \%$ \\
necessary & & & $15 \%$ \\
Uncertain demand for new products & $10 \%$ & $13 \%$ & $5 \%$ \\
Monopolised market & $8 \%$ & $8 \%$ & $1 \%$ \\
Problems finding a co-operating partner & $1 \%$ & $2 \%$ & $2 \%$ \\
Lack of information on markets & $0 \%$ & $0 \%$ & $1 \%$ \\
Lack of information on technology & $0 \%$ & $14 \%$ & $16 \%$ \\
Lack of qualified workers & $8 \%$ & $16 \%$ & $18 \%$ \\
High innovation costs & $12 \%$ & $4 \%$ & $3 \%$ \\
Lack of funding outside the enterprise & $4 \%$ & $29 \%$ & $24 \%$ \\
Lack of funding within the enterprise & $38 \%$ & & \\
\hline
\end{tabular}

Source: Source: Czech Statistical Office, 2014

The most significant factor hampering innovation activities was insufficient funding for all types of firm. This problem was seen the most amongst small companies (38\%). For large businesses, this factor was the most significant hurdle for just $24 \%$ of enterprises. High costs was a most important factor for $18 \%$ of large firms (18 \%) and for $12 \%$ of small companies. Relatively significant differences in assessments can be found for lack of qualified workers. This factor is the most relevant for $18 \%$ of large enterprises, but just for $12 \%$ of small firms. An uncertain demand for innovative products is also assessed relatively differently for various types of enterprise. It is termed the most significant factor for $15 \%$ of large businesses, but its significance falls with the size of the company. For small enterprises, it comes to just approx. $10 \%$. There are no major differences in the assessment of innovation barriers for the other factors between different size groups of the firm.

\section{Innovation categories}

The basic kinds of innovations are technical and non-technical innovations. Technical innovations are divided into product and process innovation (Herman et al. 2008; Theodor, 2008; Ahmed et al. 2010).

Table 2. gives information about types of innovation activities.

Table 2. Types of innovation activities

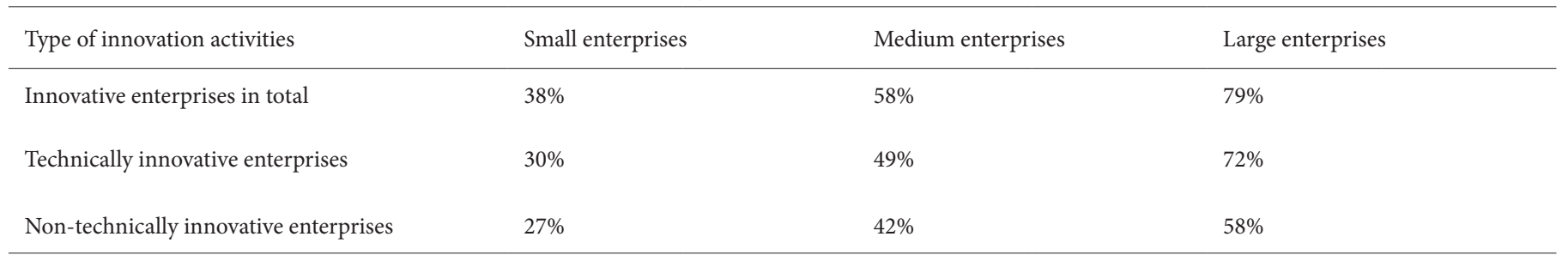

Source: Source: Czech Statistical Office, 2014

The biggest innovation activity (total) report large enterprises. The medium enterprises have the second positon, and the small enterprises have the lowest innovation activities. All three groups of enterprises are more active in the area of technical innovation in comparison with their activities in the area of the non-technical innovation.
The results of product innovation activities are (Czech Statistical Office, 2014):

Products range extension $45 \%$, Entrance into new markets $20 \%$, Replacement of the existing range of products $15 \%$, The improvement of products quality $15 \%$,

Market share increases $4 \%$, 
Negative impacts on the environment were reducing $3 \%$.

$\mathrm{Z}$ most important effect of innovation is the product range extension (45\%). The other factors have the significantly less impact. Entrance into new markets was evaluated by $20 \%$ of firms. For $15 \%$ of companies, the result of product innovation is a replacement of an existing range of products and the quality of improvement. The last two facts - market share increase and negative impacts on the environment reducing - are relevant for approximately $7 \%$ of enterprises.

The most significant result of process innovation activities are (Czech Statistical Office, 2014):

Improvement of manufacturing flexibility $57 \%$

Labour costs reducing 15\%

Negative impacts on the environment decreasing 13\%

Expansion of production capacity $8 \%$

Material and energy consumption reducing 3\%

The health and safety of workers improving $5 \%$

The most major effect of product innovation activities is an improvement of manufacturing flexibility. This result is most important for $57 \%$ of enterprises. The second most important result is labor cost reducing (approximately $15 \%$ ) and the third most crucial factor is reducing of negative impact on the environment. The other three factors - expansion of production capacity, material, and energy consumption reducing and the health and safety of workers improving have less than $10 \%$ of enterprises.

\section{Conclusion}

Innovation is the world and also in the Czech literature recognized as one of the sources of competitive advantage. According to review of the literature, the foundation of this strategy understands customer needs and value analysis. There are many barriers to the innovation development and implementation of the enterprises. The most important barrier to innovation for companies in the Czech Republic is the lack of funds.

\section{References}

Ahmed, P. K. \& Shepherd, Ch. D. (2010). Innovation management: context, strategies, systems and processes. Harlow: Prentice Hall.

Bartes, F. (2006). Nové směry v konkurenční strategii firmy. In: E. Kislingerova, H. Kopalova \& J. Krause (Eds), Nová teorie ekonomiky a managementu organizací. Praha: Oeconomica.

Bartes, F. (2010). Modern competitive strategy firm. Acta Universitatis Agriculturae et Silviculturae Mendelianae Brunensis, 58(6), 51-58. https://doi.org/10.11118/actaun201058060051

Bartes, F. (2011). Strategie konkurenčních střetů. Ostrava: Key Publishing.
Christensen, C. M. (2013). The innovator's dilemma: when new technologies cause great firms to fail. Boston: Harvard Business Review Press.

Czech Statistical Office. (2014). Innovation activities of enterprises in the Czech Republic during year 2010 - 2012. Prague: Czech Statistical Office.

Drucker, P. F. (2015). Innovation and entrepreneurship: practice and principles London: Routledge.

Grant, R. M. (2013). Contemporary strategy analysis: text and cases. Chichester: Wiley.

Heřman, J. Horová, O. \&Jakl, M. (2008). Průmyslové inovace. Praha : Oeconomica.

Johnson, G., Whittington, R. \&Scholes, K. (2011). Exploring strategy: text \& cases. Harlow: Financial Times/Prentice Hall.

Johnson, G., Whittington, R. \& Scholes, K. (2012). Fundamentals of strategy. Harlow: Financial Times/Prentice Hall.

Jones, T. (2012). On innovation: turning on innovation in your culture, teams and organization. Nevada: Essential Ideas.

Kim, W. Ch. \& Mauborgne, R. (2005a). Blue ocean strategy: how to create uncontested market space and make the competition irrelevant. Boston: Harvard Business School Press.

Kim, W.C. \& Mauborgne, R., (2005b). Blue ocean strategy: From theory to practice. California Management Review, 47(3), 105-121. https://doi.org/10.2307/41166308

Kim, W.C. \& Mauborgne, R. (2004). Blue ocean strategy. Harvard Business Review, 82(10), 76-84.

Nečadová, M. \& Brenova, L. (2009). Inovační aktivity a konkurenceschopnost firem zpracovatelského průmyslu - výsledky primárního výzkumu. Ekonomika a management, 3(2), 1-16.

Porter, M. E. (1998a). Competitive advantage: creating and sustaining superior performance New York: The Free Press.

Porter, M., E. (1998b). Competitive strategy: techniques for analyzing industries and competitors: with a new introduction. New York: Free Press.

Rasheed, H. (2012). Innovation strategy: seven keys to creative leadership and a sustainable business model. Bloomington: iUniverse, Inc.

Scholleova, H. \& Nečadova, M. (2012). Hodnocení a vývoj inovační výkonnosti České republiky. Ekonomika a management, 6 (1), 35-49.

Theodor, M. (2008). Intenzita inovací a podněty pro inovace. Ekonomika a management, 2 (3), 35-49. 
Vlček, R. (2005). Hodnotový management inovací. In: E. Kislingerová (Ed.), Ekonomika a management organizací - Nová teorie ekonomiky. Praha : Oeconomica.

Vlček, R. (2006). Hodnotový management inovací jako nástroj odlišných strategií konkurenčního boje. In: H. Kopalova \& J. Krause (Eds.), Nová teorie ekonomiky a managementu organizací. Praha: Oeconomica.
Vlček, R. (2008). Management inovací. Strategie inovací. In: E. Kislingerova, Inovace nástrojů ekonomiky a managementu organizací. Praha: C.H.Beck.

Wit, B. de \& Meyer, R. (2014). Strategy synthesis: managing strategy paradoxes to create competitive advantage. Andover: Cengage Learning.

Oslo Manual: Guidelines for Collecting and Interpreting Innovation Data, 3rd Edition. European Commission. Paris: OECD Publishing. 